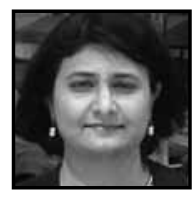

\title{
Informal Science Contexts: Implications for Formal Science Learning
}

\author{
Anila Asghar, McGill University
}

\begin{abstract}
This article illuminates the affordances of informal science learning to promote scientific literacy. It also discusses the ways in which informal learning environments can be creatively employed to enhance science instruction in K-12 as well as university settings. Also offered are various theoretical perspectives that serve as useful analytical tools to understand science learning in formal as well as informal settings.
\end{abstract}

"Children throughout the world, if we are to survive as a planet, will need to have a deep level of scientific literacy." (Chiu \& Duit, 2011, p. 553)

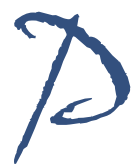

romoting a wider public understanding and appreciation of science is an overarching goal of science literacy as underscored in science education policy and curriculum benchmarks (CMEC, 1997; AAAS, 1989; NRC, 1996). Key goals of scientific literacy encompass: (a) developing a deeper understanding of science concepts; (b) developing scientific reasoning to understand the natural and designed phenomena; (c) understanding scientific research and findings, (d) recognizing scientific ideas and issues underlying socio-scientific issues; (e) formulating scientifically informed views and stances on issues of local and global importance; (e) critically evaluating scientific information from various sources; ( $f$ ) participating in debates and actions around critical social, economic, scientific, and environmental issues; and (g) pursuing careers in science, engineering, and technology (AAAS, 1993; CMEC, 1997). Contemporary science education reform efforts thus aim to develop scientifically literate citizens who can meaningfully contribute to socio-scientific discourses and engage in social and political action around them. A deeper and critical 
understanding of scientific developments and the ways in which they impact modern societies is essential to furthering the development of sustainable approaches and systems (Bybee, 1997; Chiu \& Duit; 2011; OECD, 2009).

Much of the science education reform has focused on enhancing science curricula and professional development of teachers in formal science learning contexts to meet the policy aims for science literacy. While these efforts may be very important, we are not taking into account a good deal of emerging body of research that stresses the influential role of informal science learning occurring through interactions with one's natural, technological, and cultural environments.

Science learning occurs in formal as well as informal contexts and it is extremely important for science educators to understand the ways in which it influences one's learning and views about the natural world. Although informal science environments and experiences have been significantly shaping public attitudes toward and understanding of science, the science education community has recently begun to recognize its contribution to promoting scientific literacy. Informal science learning involves social interactions and learning environments across a wide range of contexts outside of the traditional science curriculum in school, college, and university settings. Informal learning contexts include, but are not limited to, museums, science exploration centers, nature centers, zoos, aquariums, and community-based organizations. Equally important are personal experiences with machines and various technological appliances; exposure to digital and print media; online interactions; science and religion; and conversations with peers and family members around socio-scientific and ethical issues surrounding climate change, medical practices, stem cell research, biotechnology, and genetically modified organisms (Phillips, 2010; Reich, 2002; Kelly, 2000; Martin \& Reynolds, 1996; NRC, 1996).

What gives informal learning its distinctive flavor is its purely interest-driven, voluntary, self-directed, hands-on, and authentic nature (Pedretti, 2006; Dierking et al., 2003; Falk \& Dierking, 1998). The potential of informal lived experiences in terms of fostering positive attitudes and intrinsic interest in science make them a powerful source of science learning. This informal science learning occurs in multiple contexts where people can pursue their curiosity without having to worry about any formal assessment against externally stipulated performance standards (Rennie, 2007; Jung \& Tonso, 2006; Schauble et al., 1996). Informal science learning is authentic because learners develop their understandings in purposive and, therefore, authentic interactions with their social and physical environments. The results of learning are more judged against the purpose of engagement with learners' contexts and not through formal assessments against externally stipulated standards. 
Ideas gained from formal and informal contexts dynamically interact with each other in unique ways to shape an individual's scientific knowledge, opinions, and behavior. Acknowledging that formal science curriculum is not the only source of scientific ideas and understanding the nature of learning that occurs across diverse contexts in an individual's life, both within and outside of schooling environments, would help in developing a comprehensive and holistic understanding of science learning across formal and informal contexts including how informal and formal may complement and counteract each other (Kelly, 2000; Falk, 1997; Falk \& Dierking, 1992). This article argues that the contribution of informal science learning should be recognized and viewed in conjunction with formal science education in advancing scientific literacy.

This article discusses important theoretical frameworks that illuminate our understanding of the construction of knowledge in formal as well as informal contexts. Next, it presents creative models of integrated science curricula drawing on informal and formal learning approaches and findings from empirical research about the impact of such models on cognitive, affective, and social development of students and teachers.

\section{Theoretical Perspectives on Science Learning}

Despite its powerful impact on stimulating curiosity about the natural world and positive emotions toward science, informal science learning remains under-theorized in science education. Further, the cumulative and ongoing nature of science learning across myriad sites requires a comprehensive approach to understanding how scientific understanding is developed in informal as well as formal learning environments. This article draws on three theoretical frameworks that provide inclusive approaches to examine and enhance science learning in diverse learning contexts: (a) social constructivism, (b) socioculturalism, and (c) dynamic skills theory. These frameworks provide a comprehensive approach needed to understand an individual's conceptual, emotional, and historical-cultural development while engaging in authentic as well as carefully crafted science learning experiences. These theories of development also inform science educators about the pedagogical supports that can be provided to deepen students' understanding of science; develop their curiosity and interest in science; and foster problem-solving and critical thinking skills. These frameworks also serve as useful lenses to analyze how people acquire, retain, and apply scientific knowledge and the contextual factors that may enhance or inhibit their learning. 


\section{Social Constructivist Perspective}

The view that meaning is actively constructed by the learner through purposive interaction with his or her environment challenges the perspective that regards students as passive recipients of scientific knowledge (Piaget, 1972, 1985; Piaget \& Inhelder, 1969). The constructivist framework posits that knowledge is developed incrementally by expanding one's existing mental representations or schemasassimilation-and by modifying their schemas to resolve any discrepancies between the external reality and their internal representations of that reality-accommodation - to achieve equilibration. From this perspective, learning is conceived as a dialectical interplay between the processes of assimilation and accommodation. An individual constructs new knowledge by integrating new ideas into his/her existing schemas or by restructuring the schemas to interpret new information (Piaget, 1973). Given its emphasis on construction of knowledge through interaction with environments, this perspective encourages inquiry-based science pedagogy that embraces cognitive conflict experienced by the learners as a useful resource. Cognitive dissonance can be employed in inquiry-based science learning to help in restructuring one's intuitive ideas in accordance with accepted scientific models-conceptual change. Encouraging children to raise questions about physical phenomena, proposing predictions based on their explanations, testing their predictions, and comparing data with their initial expectations facilitate the process of conceptual change. From this perspective learners are construed as necessarily engaged in construction and application of their scientific knowledge. Scholars argue that application of knowledge strengthens and expands scientific understanding (Phillips, 2010; Phillips \& Norris, 2000; Falk, 1997; Carey, 1987).

The social constructivist perspective is typically seen as a challenge to a perspective that construes learning as acquisition and memorization of scientific facts and principles. Research shows that traditional approaches to formal science instruction generally promote rote memorization and often fail to address students' alternative conceptions (Asghar \& Libarkin, 2010; Asghar, 2004, 2011; Shapiro, 1994; Stead \& Osborne, 1980; Driver, 1985). Accordingly, the reform discourses construe science understanding as the ability to comprehend and solve novel problems using appropriate scientific models.

Application of theoretical knowledge to real situations requires hard thinking aimed at making connections between theory and empirical reality. While the first step in learning science involves developing theoretical ideas, the necessary next step is to make predictions about the reality using those ideas. A student may know Newton's laws and equations of motion by heart and even learn to apply them 
to routine problems generally requiring computation. Nonetheless, a deeper knowledge of physics would mean that the students could apply the laws of Newtonian physics to situations involving forces on the Earth and in space.

The social aspect of constructivist learning emphasizes that interactions with one's social environment are critical to constructing and applying new scientific knowledge. Consequently, peer interactions, discussions, collaborative reflection, and cooperative problem-solving are central to the social constructivist perspective (Martin, 2004; Crowley et al., 2001). The social constructivist framework provides a useful tool to support and examine meaningful conceptual change in a variety of formal and informal settings.

\section{Sociocultural Perspectives}

Sociocultural frameworks view learning as mediated by one's language, cultural tools, historical conditions, and active participation in community practices. Scholars argue that sociocultural theory offers a robust framework to understand and compare how students' learning is influenced by cognitive, cultural, and social practices in diverse formal and informal contexts (Geist \& Lompscher, 2003; Martin, 2004). Further, sociocultural perspectives acknowledge and attempt to understand the ways in which the power relations may influence learners' inclusion, participation, and response to learning situations. According to this view, understanding of science and socio-scientific issues grows out of one's engagement with their unique socio-political conditions, cultural values, and distinctive literacy practices. The sociocultural framework serves to enable interpretation and comparison of learning across different settings. For example, one can look at students' life culture and compare ways in which their familial and community discourses are compatible or at odds with school science and the culture of science (Donnelly, Kazempour, \& Amirshokoohi, 2009; Roth \& Lee, 2004; Geist \& Lompscher, 2003).

The sociocultural perspective is also useful as an analytical tool as it assumes learning and construction of knowledge as connected with and growing out of learners' personal, social, and political problems (Cobern, 1998; Bodker, 1989; Vygotsky, 1978; Wertsch, 1985). The pedagogical approaches flowing from this perspective encourage linkage of science concepts to the issues students confront in their everyday lives. Furthermore, these approaches encourage participation in social and political action around particular scientific, technological, and environmental issues in their communities. It also attempts to blend school and community-based learning and action through activities that have the potential to raise consciousness through 
the application of scientific knowledge to social issues. Students' involvement in issues relevant to their lives leads to intrinsic motivation and interest in learning science that could be capitalized and harnessed in building their content understanding and inquiry skills in formal as well as informal settings. Sociocultural perspectives serve to broaden and contextualize structured science curricula by including cultural venues and social issues that make science accessible and meaningful to learners (Verma, 2009). Moreover, these perspectives help to examine, compare, and integrate formal and informal learning opportunities to foster holistic development of learners.

\section{Dynamic Development Perspective}

The dynamic skill theory provides a conceptual framework to explain knowledge construction through the interaction of the individual with his or her environment (Fischer, 1980; Fischer \& Bidell, 1998). The skill is the capacity to organize mental representations, emotions, and actions within a given context in relation to a specific learning task (Mascolo \& Margolis, 2004). Fischer (1980) defines skills mutually by the "organism and environment." The construction of skills is dependent on and embedded in the person's specific social context (Fischer \& Bidell, 1998; Fischer \& Yan, 2002). The development of skills takes place when an individual undertakes a learning task in the context of his or her broader environment. Moreover, an individual's emotional response to both the task and the environment in which it unfolds is immensely important in shaping his or her learning and development.

Dynamic skill model offers a useful lens to examine learning comprehensively in terms of learners' emotional and conceptual development. The development of progressively more complex skills - thoughts, feelings, and actions-is an outcome of an individual's specific learning tasks and the conditions in which those tasks occur (Ayoub \& Fischer, 2006; Ayoub, Fischer, \& O'Connor, 2003; Fischer \& Ayoub, 1996; Fischer \& Granott, 1995). The dynamic skills perspective is more comprehensive than constructivist perspectives inasmuch as it views the development of human reasoning as a function of its social and historical contexts, and not just purposive interaction with the physical environments independent of such contexts.

Dynamic skill theory defines a developmental scale and a series of rules and methods for analyzing an individual's thoughts and actions in the process of his or her development. Skills develop as children coordinate lower-level actions into higher-order wholes within particular tasks, conceptual domains, and sociocultural learning situations. Human development is conceptualized in terms of progressing 
through four stages of development. In each stage the individual exhibits a new ability that builds upon the structures of earlier stages. The development of skills proceeds through four major tiers of developmental changes between birth and thirty years of age: (a) reflexes, (b) sensorimotor actions, (c) representations, and (d) abstractions (Fischer \& Farrar, 1987). The skills become increasingly complex and qualitatively different at each level through a process of "coordination" by integrating lowerlevel skills into more complex and sophisticated skills (Bidell \& Fischer, 1992; Fischer \& Rose, 1994). The transformation of skills as they become more complex and higher order produces gradual and continuous changes in behaviour. For example, all skills in the sensorimotor tier consist of sensorimotor sets-actions, objects, events, or people. Infants can control only sensorimotor action. They act on objects in their environment, but they have not achieved the ability to think that objects, events, people have attributes independent of the infant's actions. At this stage an infant can control activities like looking at a doll for long periods of time; keeping the moving gadgets in the field of vision; and grasping the objects when they touch the child's hands. The representational tier is characterized by a relationship between two or more sensorimotor systems. The child at this level develops the potential to combine disparate sensorimotor systems to generate single or complex representational sets. For example, children can coordinate different variables to develop the ideas of conservation of mass, length, and volume. At this level intentions guide actions. In social relations the child constructs an understanding of the relationship between his or her own intention vis-à-vis another person's intentions (Fischer \& Bidell, 1998).

According to dynamic skill theory, learning and development involve integration and differentiation of skills-thoughts, actions, and feelings. Importantly, it recognizes the role of affect in organizing and shaping cognitive skills (Asghar, 2004; Ayoub \& Fischer, 2006). Research shows that students with high anxiety either quit science because they find it hard or take fewer science classes in college (Tobias, 1990, 1992, 1993). The dynamic skills model predicts a correlation between cognitive and emotional dimensions at every general level of development. In the early stages of development children see things in terms of positive and negative split; they consider negative and positive characteristics and behaviours as mutually exclusive. People, actions, and experiences are either good or bad. A child, for instance, may think that science is boring because it is difficult to understand. The skills are focused only on the negative aspects of science. However, as the control systems become more complex, children become aware that good and bad could exist in the same situation and people. For example, a child understands that some aspects of science could be fun, such as doing interesting experiments, while others could be boring, such as repeating the same experiments many times. 
The pedagogical implications of the dynamic skills model involve its use as an effective tool to develop appropriate contextual supports that teachers, parents, and online communities can provide to promote students' interest in and understanding of science. This model posits that individuals are able to function at higher levels in contexts that provide high rather than low levels of social support (Asghar, 2004; Rogoff, 2003; Parziale, 1997). For example, adolescents can be supported to develop complex abstract relations in high support contexts depending on their level of engagement and the amount of support they are receiving from their environment (teacher, parent, or older siblings).

Taken together, these theoretical frameworks help in conceptualizing and analyzing science learning in various traditional and non-traditional contexts. They can enhance science education researchers' and practitioners' understanding of how learners approach their learning tasks; what they actually learn; how they relate to their learning activities at an emotive level; and how they understand and apply their science knowledge to solve myriad scientific issues in their broader social, political, and cultural environments.

\section{Infusing Informal Science Opportunities Into Formal Science Education}

“...[M]useum field trips - regardless of type, subject matter, or nature of the lessons presented - result in highly salient and indelible memories. These memories represented evidence of learning across a wide array of diverse topics." (Falk \& Dierking, 1997, p. 216)

Informal experiences with science through interaction with myriad resources outside of the school have become a vital source of curriculum enrichment. Partnerships between schools, scientists, and museums may offer rich and meaningful science learning opportunities for students and their teachers (Katz et al., 2011; Kisiel, 2005, 2006). Innovative models of school-museum partnerships have been developed to enhance student learning in science. This section presents examples of such ongoing collaborations among schools, science museums, nature centers, and community-based science projects.

Museums and other similar venues offer stimulating environments for engagement in explorations. As the theoretical perspectives discussed earlier 
suggest, science learning is a social, collaborative, and cumulative process occurring over an individual's life in myriad settings. Research suggests that museum and other such free-choice settings cultivate an intrinsic desire and curiosity to learn science (Kelly, 2000; Russell, 1996). Museum exhibits and investigations can be carefully integrated into science curriculum to: (a) spark students' imagination and sense of wonder about the natural world; (b) stimulate their interest in particular science topics; (c) develop their questions to plan and pursue scientific investigations; (d) promote conceptual change through discussion, reflection, and cognitive conflict; (e), organize cooperative inquiry projects, $(f)$ extend students' emerging understandings of particular scientific models; (e) provide authentic problem-solving tasks; and (f) facilitate social interactions and cultural development.

Research suggests that teachers can design effective and interesting plans for inquiry-based science instruction by connecting curriculum to museum exhibits (Anderson, Lucas, \& Ginns, 2003; Kisiel, 2006; Falk \& Dierking, 1992). Nonetheless, some scholars argue that although museum fieldtrips enhance "visitor engagement, understanding, and recall" (Allen, 2004, p. 30), it is not clear how these "fragmented" experiences impact children's ability to extract abstract scientific principles (CoxPetersen et al., 2003; Abraham-Silver, 2006; Allen, 2004; Anderson, 1994). Hence, as educators it is our "responsibility" to "push these discrepant event experiences, these moments of heightened curiosity, to the next level," argues Abraham-Silver (2006, p. 12). She further adds, "Critical to meaningful science education is continued attention to bringing authenticity into the learning experience. This is where classroom teachers and informal science educators can meet and make a difference" (p. 12).

Presented below are some examples of the collaborative approaches to construct interactive and reflective learning spaces for students by creatively infusing informal activities into the science curriculum. The studies discussed in this section demonstrate how less formal activities could be used to enhance science instruction and offer evidence-based practices to augment student interest and participation in science. Notably, these concrete activities exemplify the theoretical perspectives set forth in the preceding section. Specifically, they illuminate how the principles and practices of the learning theories discussed above could be employed to promote students' affective development and cognitive growth through creation, coordination, and integration of new representations; conceptual understanding through discussions and interactions with their social environment; and active engagement with their communities to address socio-scientific issues through problem-solving and collaborative action. 


\section{Anticipating and Scaffolding to Sustain Conceptual Change}

Using the constructivist framework, Anderson and colleagues (2003) examined students' emerging understanding of science concepts through a series of activities before, during, and after a museum visit. This study highlighted the importance of using post-visit activities to reinforce students' science ideas gained through their interaction with the museum exhibits on electricity and magnetism. Students' construction of scientific knowledge was investigated through post-visit concept maps and interviews. This study provides evidence that an integrated series of preand post-visit activities may result in conceptual change consistent with the accepted scientific models. These findings also underscore the importance of planning preand post-visit activities explicitly linked to the museum explorations to scaffold and strengthen students' emergent understandings. Besides supporting the development of scientific conceptions, such activities also help in identifying and preempting the development of potential alternative conceptions in these informal science learning venues.

\section{Making Science Learning Meaningful Through Situational Resources}

Employing the situational approach, Dohn (2011) examined how high school biology students' interest in learning emerged during a field visit to an aquarium. This case study particularly illuminated the situational factors that stimulated students' motivation to engage in science learning regardless of prior interest. The aquarium visit was a part of a 10-week unit on ecology and population biology. The students prepared for the aquarium visit by first reading a scientific text about ecology. The reading helped them to select particular organisms to observe during the aquarium visit. Post-visit activities in the classroom included evaluation and follow-up learning experiences related to the aquarium trip. The researchers used participant observations, video recording, and interviews to examine student learning. The following situational factors significantly contributed to student learning: (a) knowledge-based interest; (b) social interactions and cooperative learning while performing the tasks; (c) hands-on sensory experiences with different kinds of organisms; (d) surprising or unexpected discoveries related to biodiversity during field explorations; and (e) novel or unusual phenomena observed during the field trip.

\section{Synergy Between Science, Technology, and Society as an Aid to Learning}

Dori and Tal (2000) shared a unique collaborative model of an integrated science, technology, and society (STS) curriculum involving 6th graders, teachers, 
parents, and local community members. This curriculum drew on synergistic schoolcommunity partnerships around environmental issues. These collaborative projects creatively combined formal and informal learning and assessment approaches, such as problem-based learning activities, case studies, field trips, and formal class sessions. Parents, teachers, and local community experts worked with students in groups to help them select project themes concerning industrial and environmental awareness (e.g., road improvement, waste industry, etc.). These groups also decided upon the criteria for designing products related to their chosen project themes through mutual consultation. Care was taken to develop projects that could potentially contribute to the township community. The groups also carefully considered the environmental impact of their products and developed appropriate solutions to address any unfavorable effects on the environment. Some examples of the collectively designed products were: a wastebasket with various recycling bins, and a lighted map to help locate each home in the community. A combination of informal and formal assessment strategies was employed to gauge learning outcomes, such as evaluation of collaborative products by local experts and assessment of students' conceptions and attitudes through pre- and post-course instruments. These evaluation measures revealed significant improvements in students' knowledge, attitudes, and problem-solving skills. Further, students developed a more comprehensive understanding of real-world environmental problems and their social, economic, and political consequences.

\section{Learning to Teach Science: Affordances of the Informal}

Teaching science is far more complex and involved than merely classroom lectures and textbook reinforcement; it requires hands-on activity, but it also calls for minds-on explorations that engage learners in thoughtful, reflective investigations that promote hypothesizing and questioning and foster a genuine interest and curiosity in the subject. (Kelly, 2000, p. 758)

Continued professional development of teachers is key to effective integration and implementation of informal learning approaches in science instruction. Practitioners and scholars have identified particular principles of effective professional development for science teachers in accordance with the goals of science education reform. These principles focus on (a) building teachers' knowledge of the nature of science and its epistemological foundations; (b) deepening teachers' understanding 
of science concepts; (c) developing their pedagogical content knowledge; and (d) immersing teachers in real-world science problems and processes (Loucks-Horsley et al., 2003; NRC, 1999). Nonetheless, many science teachers experience a disconnect between the traditional instructional approaches used in their methods courses and those that they are expected to use in their classroom practice (Katz et al., 2011; Topcu, Yilmaz-Tuzuun, \& Sadler, 2011; Riedinger et al., 2011).

Research suggests that teachers' positive feelings and attitude toward science impact their teaching and curricular decisions (Kelly, 2000). Informal science experiences have been shown to increase teachers' interest in and appreciation of science. Studies with teachers in museum settings indicate that interactions with exhibits and subsequent reflections on their learning and struggles help teachers integrate, understand, and apply their pedagogical content knowledge to develop inquiry-based lesson plans for their own students (Riedinger et al., 2011; Jung \& Tonso, 2006).

Different models of teacher education have been developed to make professional preparation meaningful and culturally relevant for teachers by infusing informal learning opportunities into science education curricula. Presented here are a few examples of elementary science methods courses that illustrate the ways in which science preparation programs can benefit from informal learning spaces.

\section{Integrating Outreach Activities and Virtual Tours Into Science Methods Courses}

Riedinger and colleagues (2011) conducted an experimental study with prospective elementary teachers in an undergraduate science methods course. The treatment course included various components of informal science education including live animal demonstrations, guest lectures by informal science educators, and "virtual fieldtrips" to museums. Different sources of data included field notes, researchers' reflections, student evaluations, and pre/post-surveys to investigate preservice teachers' beliefs about the nature of science.

The course instructors invited science educators to share informal outreach initiatives with the teacher candidates. The prospective teachers experimented with informal activities with their peers or their families and reported their findings to the whole class. They also adapted some outreach activities for their future classrooms. Another interesting feature of this curriculum was the use of guided virtual fieldtrips to museums and exploration of online exhibits on climate change. Discussions on 
such experiences sought ways of incorporating the informal online activities into formal science lesson plans. The study found that the prospective teachers in the treatment group experienced significant transformations in their attitudes toward and appreciation of science. The authors attribute this change in attitudes to the affective components of informal science learning.

\section{Student Teaching at a Science Museum}

Kelly (2000) describes the impact of informal learning experiences on prospective teachers' pedagogical content knowledge. Besides observing actual elementary classrooms and practice teaching with small groups of elementary students, the teacher candidates developed teaching units and implemented them at a local science museum with small groups of students. The rich environment of the museum sparked students' interest and engagement with science explorations. Data were gathered through a variety of tools to assess the effectiveness of the course. These data included interviews with the course participants and graduates and observations of the science units implemented at the museum. Pre- and post-course questionnaires were also administered to gauge students' attitudes toward science, confidence in their teaching ability, and knowledge of content, pedagogy, and learning environments.

The informal learning environment served to promote a deeper understanding of scientific concepts, fostered teachers' problem-solving capacities, and reflective practice. Specifically, the informal experiences focused on the acquisition and applications of science content and relevant pedagogical knowledge to their teaching practice through hands-on inquiry, group work, dialogue, and reflective journals. Teacher candidates reported an increased confidence in their ability to creatively employ museum resources to promote children's inquiry skills and understanding of science. In this process they also developed a sophisticated understanding of the content related to the museum explorations that they used in their teaching units (e.g., microbiology, light, color). Doing science in a "non-structured" resource-rich environment was rewarding and so was the process of learning different concepts with children during the hands-on activities. Not only did they learn about science, but they also learned about how scientific knowledge was created through a purposive engagement with their environment. These interactive experiences also changed their initial views of science as boring, uninteresting, and based only on hard facts. Interviews with some graduates of this program who were teaching in schools suggested that they were using elements of their museum learning units in their classroom teaching. 
The author notes that "even a single science methods course based on a holistic, constructivist approach can reform and enhance teacher knowledge, confidence, and attitudes and may lead to the utilization of constructivist strategies in teaching science in the elementary science classroom" (Kelly, 2000, p. 772).

\section{Enacting Safe Spaces to Support Teachers' Learning}

Jung and Tonso (2006) conducted a similar study with pre-service elementary teachers to look at ways to support them in developing effective content pedagogical knowledge. They also explored the potential of out-of-school settings, such as museums and nature centers to create safe, supportive, and nurturing spaces for student teaching. The rich and robust informal learning environments provided sites of meaningful application of the knowledge and skills gained in the science methods course. Student teachers prepared and taught thematic units to small groups of children at a museum or nature centers. Data were collected through participant observations of teachers' lessons, surveys, and interviews with student teachers. Teacher candidates received training from scientists and museum or nature center educators about the learning resources and science concepts involved in the exhibits and activities. The factors that were immensely appreciated by the teachers constituted team-teaching; a flexible environment where they could figure out their own pedagogical styles; and no fear of evaluation as they received a grade for completing their teaching assignments. The authors suggest that the use of safe spaces in informal settings can potentially contribute to reform efforts in science education. Further, interactions with scientists and science education experts enhanced teachers' scientific knowledge and also helped in diagnosing and addressing their alternative conceptions.

The principles and theories of learning discussed in this article and the studies with children and teacher support the assertion that science learning cannot be confined to lectures, rote memorization, and an isolated set of laboratory experiments disconnected from learners' everyday lives. Science learning is a lifelong process that occurs in multiple contexts through varied personal, social, and political experiences. Thus science learning should be understood, analyzed, and imparted holistically across formal and informal contexts. The challenge for science educators, practitioners, and researchers is how to harness these learning affordances effectively. Further research is needed to examine the factors that can contribute to sustained learning, motivation, and self-regulation in science education. 


\section{References}

Abraham-Silver, L. (2006). Valuing informal science learning environments. The Science Teacher, 73(1), 12.

Allen, S. (2004). Designs for learning: Studying science museum exhibits that do more than entertain. Science Education, 88, S17S33.

American Association for the Advancement of Science (AAAS). (1989). Project 2061: Science for all Americans. New York: Oxford University Press.

American Association for the Advancement of Science (AAAS). (1993). Benchmarks for science literacy. New York: Oxford University Press.

Anderson, D. (1994). The effect of pre-orienting year eight students to the informal learning environment of a science museum on cognitive learning. Unpublished Master of Education thesis, Queensland University of Technology, Brisbane, Australia.

Anderson, D., Lucas, K. B., \& Ginns, I. S. (2003). Theoretical perspectives on learning in an informal setting. Journal of Research in Science Teaching, 40, 177-199.

Asghar, A. (2004). Exploring children's cognitive and affective skills using Fischer's dynamic skills model. Unpublished doctoral dissertation. Harvard University.

Asghar, A. (2011). Differentiating science pedagogy. In F. Ornek and I. M. Saleh (Eds.), Contemporary science teaching approaches. Germany: VDM Publishing House.

Asghar, A., \& Libarkin, J. (2010). Gravity, magnetism, and 'down': College students' conceptions of gravity. The Science Education, $19(1), 42-55$.

Ayoub, C., \& Fischer, K. (2006). Developmental pathways and intersections among domains of development. In K. McCartney \& D. Phillips (Eds.), The Blackwell handbook of early child development (pp. 62-81). Oxford: Blackwell.

Ayoub, C., Fischer, K., \& O'Connor, E. (2003). Analyzing development of working models for disrupted attachments: The case of family violence. Attachment and Human Development, 5, 97-120.
Bidell, T., \& Fischer, K. (1992). Beyond the stage debate: Action, structure, and variability in Piagetian theory and research. In C. Berg \& R. Sternberg (Eds.), Intellectual development (pp. 100-140). New York: Cambridge University Press.

Bodker, S. (1989). Through the interface: A human activity design approach to computer interface design. Human Computer Interaction, 4(3), 171-195.

Bybee, R. W. (1997). Towards an understanding of scientific literacy. In W. Graber \& C. Bolte (Eds.), Scientific literacy (pp. 37-68). Kiel, Germany: Institute for Science Education (IPN).

Carey, S. (1987). Conceptual change in childhood. Cambridge, MA: MIT Press.

Chiu, M., \& Duit, R. (2011). Globalization: Science education from an international perspective. Journal of Research in Science Teaching, 48(6), 553-566.

Cobern, W. W. (1998). Socio-cultural perspectives on science education: An international dialogue. Boston: Kluwer Academic Publishers.

Council of Ministers of Education, Canada (CMEC). (1997). Common framework of science learning outcomes: Pan-Canadian protocol for collaboration on school curriculum. Ottawa, Canada: Author.

Cox-Petersen, A. M., Marsh, D. D., Kisiel, J., \& Melber, L. M. (2003). Investigation of guided school tours, student learning, and science reform recommendations at a museum of natural history. Journal of Research in Science Teaching, 40, 200-218.

Crowley, K., Callanan, M. A., Tenenbaum, H. R., \& Allen, E. (2001). Parents explain more often to boys than to girls during shared scientific thinking. Psychological Science, 12(3), 258-261.

Dierking, L. D., Falk, J. H., Rennie, L., Anderson, D., \& Ellenbogen, K. (2003). Policy statement of the "Informal Science Education" Ad Hoc Committee. Journal of Research in Science Teaching, 40(2), 108-111. 
Dohn, N. B. (2011). Situational interest of high school students who visit an aquarium. Science Education, 95, 337-357.

Donnelly, L.A., Kazempour, M., \& Amirshokoohi, A. (2009). High school students' perceptions of evolution instruction: Acceptance and evolution learning experiences. Research in Science Education, 39, 643-660.

Dori, Y.J., \& Tal, B.T. (2000). Formal and informal collaborative projects: Engaging in industry with environmental awareness. Science Education, 84(1), 95-113.

Driver, R. (1985). Children's ideas in science. Milton Keynes, UK: Open University Press.

Falk, J.H. (1997). Testing a museum exhibition design assumption: Effect of explicit labeling of exhibit clusters on visitor concept development. Science Education, 81, 679-687.

Falk, J. H., \& Dierking, L. D. (1992). The museum experience. Howells House, Washington, DC.

Falk, J. H., \& Dierking, L. D. (1997), School field trips: Assessing their long-term impact. Curator: The Museum Journal, 40, 211-218.

Falk, J.H., \& Dierking, L.D. (1998, May/June). Free-choice learning: An alternative term to informal learning? Informal Learning Environments Research Newsletter (p. 2). Washington, DC: American Educational Research Association.

Fischer, K. (1980). A theory of cognitive development: The control and construction of hierarchies of skills. Psychological Review, $87,477-531$.

Fischer, K., \& Ayoub, C. (1996). Analyzing development of working models of close relationships: Illustration with a case of vulnerability and violence. In G. Noam \& K. Fischer (Eds.), Development and vulnerability in close relationships (pp. 173-199). Mahwah, NJ: Erlbaum.

Fischer, K., \& Bidell, T. (1998). Dynamic development of psychological structures in action and thought. In D. W. (Ed.), Handbook of child psychology. New York: Wiley.
Fischer, K., \& Farrar, M. J. (1987). Generalizations about generalizations: How a theory of skill development explains both generality and specificity. International Journal of Psychology, 22, 643-677.

Fischer, K., \& Granott, N. (1995). Beyond onedimensional change: Parallel, concurrent, socially distributed process in learning and development. Human Development, 38, 302-314.

Fischer, K., \& Rose, S. (1994). Dynamic development of coordination of components in brain and behavior: A framework of theory and research. In G. Dawson \& K. Fischer, (Eds.), Human behavior and the developing brain (pp. 3-66).

Fischer, K., \& Yan, Z. (2002). The development of dynamic skill theory. In R. Lickliter \& D. Lewkowicz (Eds.), Conceptions of development: Lessons from the laboratory. Hove, UK: Psychology Press.

Geist, H., \& Lompscher, J. (2003). Formation of learning activity and theoretical thinking in science teaching. In A. Kozulin, B. Gindis, V. S. Ageyev, S. M. Miller (Eds.) Vygotsky's educational theory in cultural context (pp. 267-288). New York: Cambridge University Press.

Jung M. L., \& Tonso, K. L. (2006). Elementary preservice teachers learning to teach science in science museums and nature centers: A novel program's impact on science knowledge, science pedagogy, and confidence teaching. Journal of Elementary Science Education, 18(1), 15-31.

Katz, P. J. McGinnis, R. Hestness, E., Riedinger, K., Marbach-Ad, G., Dai, A., et al. (2011). Professional identity development of teacher candidates participating in an informal science education internship: A focus on drawings as evidence. International Journal of Science Education, 33(9), 1169-1197.

Kelly, J. (2000). Rethinking the elementary science methods course: A case for content, pedagogy, and informal science education. International Journal of Science Education, 22(7), 755-777.

Kisiel, J. (2005). Understanding elementary teacher motivations for science fieldtrips. Science Education, 89, 936-955. 
Kisiel, J. (2006). An examination of fieldtrip strategies and their implementation within a natural history museum. Science Education, 90, 434-452.

Loucks-Horsley, S., Love, N., Stiles, K. E., Mundry, S., \& Hewson, P. W. (2003). Designing professional development for teachers of science and mathematics. Thousand Oaks, CA: Corwin Press.

Martin, L. M. W. (2004). An emerging research framework for studying informal learning and schools. Science Education, 88, S71S82.

Martin, K., \& Reynolds, S. (1996). The learning laboratory: an ongoing conversation. The Constructivist, 11, 15-20.

Mascolo, M. F., \& Margolis, D. (2004). Social cognition as a mediator of adolescent development: A coactive systems approach. European Journal of Developmental Psychology, 1(4), 289-302.

National Research Council (NRC). (1996). National science education standards. Washington, DC: National Academy Press.

National Research Council (NRC). (1999). How people learn: Brain, mind, experience and school. J. Bransford, Brown, A, \& Cockling, R. (Eds). Washington, DC: National Academy Press.

Organization for Economic Co-operation and Development (OECD). (2009). Assessing scientific, reading and mathematical literacy-A framework for PISA (2009). Paris, France: OECD.

Parziale, J. (1997). Microdevelopment during an activity based science lesson. Unpublished doctoral dissertation, Harvard University, Cambridge, MA.

Pedretti, E. (2006). Informal science education: Critical conversations and new directions. Canadian Journal of Science, Mathematics and Technology Education, 6(1), 1-4.

Phillips, L., \& Norris, S. (2000). Interpreting popular reports of science: What happens when the reader's world meets the world on paper? International Journal of Science Education, 21, 317-327.
Phillips, M. (2010). Research trends and findings from a decade (1997-2007) of research on informal science education and freechoice science learning. Visitor Studies, 13(1), 3-22.

Piaget, J. (1972). The child's conception of physical causality. Totowa, NJ: Littlefield, Adams.

Piaget, J. (1973). The child's conception of the world. London: Paladin.

Piaget, J. (1985). Equilibration of cognitive structures. University of Chicago Press.

Piaget, J., \& Inhelder, B. (1969). The psychology of the child. New York: Basic Books.

Reich, R. (2002). The future of success: Working and living in the new economy. New York: Vintage.

Rennie L. J. (2007). Learning science outside of school. In S. K. Abell, N. G., Lederman (Eds.) Handbook of research on science education (pp 125-167). Lawrence Erlbaum, Mahwah.

Riedinger, K., Marbach-Ad, G., McGinnis, J. R., Hestness, E., \& Pease, R. (2011). Transforming elementary science teacher education by bridging formal and informal science education in an innovative science methods course. Journal of Science Education and Technology, 20(1), 51-64.

Rogoff, B. (2003). The cultural nature of human development. New York: Oxford University Press.

Roth, W., \& Lee, S. (2004). Science education as/ for participation in the community. Science Education, 88, 263-291.

Russell, R. L. (1996). The role of science museums in teacher education. Informal Science Review, 19, 16.

Schauble L., Beane, D. B., Coates. G. D., Martin, L. M., \& Sterling, P. V. (1996). Outside the classroom walls: Learning in informal environments. In L. Schauble, R. Glaser (Eds.), Innovations in learning: New environments for education (pp. 5-24). Lawrence Erlbaum, Mawhaw.

Shapiro, B. (1994). What children bring to light. New York: Teachers College Press. 
Stead, K., \& Osborne, R. (1980). Gravity. A working paper of the learning in science project. Hamilton, New Zealand: University of Waikato, Science Education Research Unit.

Tobias, S. (1990). They're not dumb, they're different: Stalking the second tier. Tucson, AZ: Research Corporation.

Tobias, S. (1992). Revitalizing undergraduate science: Why some things work and most don't. Tucson, AZ: Research Corporation.

Tobias, S. (1993). What makes science hard? Journal of Science Education and Technology, 2, 297-304.
Topcu, M., Yilmaz-Tuzuun, O., \& Sadler, T. (2011). Turkish preservice science teachers' informal reasoning regarding socioscientific issues and the factors influencing their informal reasoning. Journal of Science Teacher Education, 22(4), 313-332.

Verma, G. (2009). Science and society in the classroom. Using sociocultural perspectives to develop science education. New York: Cambria Press.

Vygotsky, L.S. (1978). Mind and society: The development of higher mental processes. Cambridge, MA: Harvard University Press.

Wertsch, J. V. (1985). Vygotsky and the social formation of mind. Cambridge, MA: Harvard University Press.

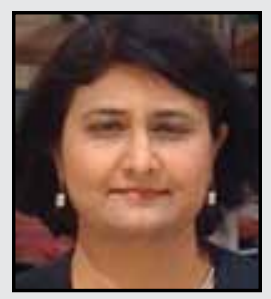

Anila Asghar is an Assistant Professor in the Department of Integrated Studies in Education at McGill University. Prior to joining McGill she was an Assistant Professor at the Johns Hopkins School of Education. Her research focuses on cognitive and emotional development while learning science, conceptual change, and problem-based learning in science/STEM education. She has also been looking at science education reform and the interactions among science, culture, and religion in diverse international contexts. 